Article

\title{
White Shrimp Litopenaeus vannamei That Have Received Gracilaria tenuistipitata Extract Show Early Recovery of Immune Parameters after Ammonia Stressing
}

\author{
Yu-Yuan Chen, Jiann-Chu Chen *, Yong-Chin Lin, Su-Tuen Yeh and Chien-Lun Huang \\ Department of Aquaculture, College of Life Sciences, National Taiwan Ocean University, \\ Keelung 202, Taiwan; E-Mails: fivedollarboy555@yahoo.com.tw (Y.-Y.C.); \\ d91330003@mail.ntou.edu.tw (Y.-C.L.); d92330006@ntou.edu.tw (S.-T.Y.); \\ m96330013@ntou.edu.tw (C.-L.H.) \\ * Author to whom correspondence should be addressed; E-Mail: jcchen@mail.ntou.edu.tw; \\ Tel./Fax: +886-2-2462-0295.
}

Academic Editor: Colin Barrow

Received: 19 March 2015 / Accepted: 21 May 2015 / Published: 5 June 2015

\begin{abstract}
White shrimp Litopenaeus vannamei immersed in seawater (35\%) containing Gracilaria tenuistipitata extract (GTE) at 0 (control), 400, and $600 \mathrm{mg} / \mathrm{L}$ for $3 \mathrm{~h}$ were exposed to $5 \mathrm{mg} / \mathrm{L}$ ammonia-N (ammonia as nitrogen), and immune parameters including hyaline cells (HCs), granular cells (GCs, including semi-granular cells), total hemocyte count (THC), phenoloxidase (PO) activity, respiratory bursts (RBs), superoxide dismutase (SOD) activity, lysozyme activity, and hemolymph protein level were examined $24 \sim 120 \mathrm{~h}$ post-stress. The immune parameters of shrimp immersed in $600 \mathrm{mg} / \mathrm{L} \mathrm{GTE}$ returned to original values earlier, at 96 120 h post-stress, whereas in control shrimp they did not. In another experiment, shrimp were immersed in seawater containing GTE at 0 and $600 \mathrm{mg} / \mathrm{L}$ for $3 \mathrm{~h}$ and examined for transcript levels of immune-related genes at $24 \mathrm{~h}$ post-stress. Transcript levels of lipopolysaccharide and $\beta$-1,3-glucan binding protein (LGBP), peroxinectin (PX), cytMnSOD, mtMnSOD, and HSP70 were up-regulated at $24 \mathrm{~h}$ post-stress in GTE receiving shrimp. We concluded that white shrimp immersed in seawater containing GTE exhibited a capability for maintaining homeostasis by regulating cellular and humoral immunity against ammonia stress as evidenced by up-regulated gene expression and earlier recovery of immune parameters.
\end{abstract}


Keywords: Litopenaeus vannamei; Gracilaria tenuistipitata extract; ammonia stress; immune parameters; gene expressions

\section{Introduction}

Like other invertebrates, shrimp do not produce immunoglobulin and rely instead on an innate immunity to detect and respond to microbial antigens like lipopolysaccharide (LPS), $\beta$-1,3-glucan $(\beta G)$, and peptidoglycan (PG), known as pathogen-associated molecular patterns (PAMPs) [1-3]. PAMP recognition is achieved through pattern-recognition proteins (PRPs) or pattern-recognition receptors (PRRs) that circulate freely in the hemolymph and initiate an immune response that includes phagocytosis, nodule formation, encapsulation, synthesis of antimicrobial peptides, and the propenoloxidase (proPO) cascade [2,4,5]. Lipopolysaccharide and $\beta$-1,3-glucan binding protein (LGBP) is an important PRP that occurs in several species of penaeids, including white shrimp Litopenaeus vannamei $[6,7]$.

Hemocytes have a crucial role in host immune activity, including cellular and humoral reactions [5]. Among the hemocytes, semi-granular cells (SGCs) and granular cells (GCs) are both induced to degranulate the granules by foreign particles like LPS and $\beta G$ and subsequently release several proteins including proPO, prophenoloxidase activating enzyme (ppA), peroxinectin ( $\mathrm{PX})$, proteinase inhibitors, and lysozyme [4,5]. In the proPO system and proteinase inhibitor system, ppA, proPO, and $\alpha 2$-macroglobulin ( $\alpha 2-\mathrm{M})$ are important molecules [8,9]. Phenoloxidase (PO), a terminal enzyme in the proPO cascade, is the active form of proPO which is converted by an endogenous trypsin-like serine proteinase, or ppA leading to melanin formation [5]. PO plays a key role in recognition and defense against pathogen infections [10,11]. Peroxinectin (PX) and integrin are the important signaling transduction molecules $[8,12,13]$.

Hyaline cells (HCs) are involved in phagocytosis, an important process for eliminating microorganisms $[14,15]$. The respiratory burst $(\mathrm{RB})$ that occurs during the process of phagocytosis, leads to the formation of the superoxide anion and other reactive oxygen species (ROS). The superoxide anion and its derivatives are bactericidal [16]. Superoxide dismutase (SOD) scavenges the superoxide anion, prevents the generation of the highly toxic hydroxyl radical $(\cdot \mathrm{OH})$, and catalyses the dismutation of the superoxide anion to form molecular oxygen and hydrogen peroxide [17]. In white shrimp, cytosolic manganese superoxide dismutase (cytMnSOD), mitochondrial manganese superoxide dismutase (mtMnSOD), and extracellular copper-zinc superoxide dismutase (ecCuZnSOD) are important anti-oxidant enzymes ([18-20], KP09968). HSP70 is an environmentally inducible heat shock protein (HSP), and acts as a chaperone in regulating normal protein function ([21], AY645906).

The white shrimp is the dominant species currently cultured in the Pacific Rim countries [22]. Shrimp farming has high stocking densities that result in deteriorated environments due to accumulations of organic wastes and metabolic wastes like ammonia, nitrite, and sulfide [23,24]. Ammonia concentration increases directly with the culture period and reaches as high as $7 \mathrm{mg} / \mathrm{L}$ ammonia-N (ammonia as nitrogen) in intensive grow-out shrimp farms [23]. The 96-h 50\% lethal concentration (median lethal concentration, $\left.\mathrm{LC}_{50}\right)$ of ammonia-N on white shrimp $(22 \pm 2.4 \mathrm{~mm}$ 
length) at $35 \%$ and $23{ }^{\circ} \mathrm{C}$ is $39.54 \mathrm{mg} / \mathrm{L}$ [25]. High levels of ammonia in water decrease survival, growth, and osmoregulation of shrimp as well as resistance to Vibrio alginolyticus, a pathogenic bacterium isolated from diseased white shrimp [26-28]. Therefore, management of optimal water quality parameters including low concentration of ammonia and maintenance of immunity in shrimp are of primary concern.

White shrimp that received red seaweed Gracilaria tenuistipitata extract (GTE) via immersion, injection, and diet experienced an enhancement of immune responses [29-31]. White shrimp that received GTE via immersion show an earlier recovery of immune parameters after temperature and salinity stressing $[32,33]$. White shrimp that received GTE via immersion show an earlier recovery of immune parameters after a Vibrio alginolyticus challenge and the combined stresses of a $V$. alginolyticus challenge and temperature change [30,33]. White shrimp that received GTE via immersion show lesser decreases in immune parameters after white spot syndrome virus (WSSV) challenges compared to controls [34]. White shrimp fed a diet containing GTE show increased resistance to $V$. alginolyticus and WSSV challenges [31]. However, little or nothing is known about immune responses and gene expressions of shrimp that have received the extract under ammonia stressing.

We assume that white shrimp that received GTE may show earlier recovery when subjected to ammonia stress. Accordingly, the purpose of this study was to examine (1) the immune parameters, and (2) transcript levels of LGBP, PX, integrin $\beta$ (IB), ppA, proPO I, proPO II, $\alpha 2-\mathrm{M}$, cytMnSOD, mtMnSOD, ecCuZnSOD, and HSP70 of shrimp immersed in seawater containing GTE and then exposed to ammonia. Immune parameters, HCs, GCs (including semi-granular cells), total hemocyte count (THC), phenoloxidase (PO) activity, RB, superoxide dismutase (SOD) activity, lysozyme activity, and hemolymph protein level were examined.

\section{Results}

\subsection{Immune Parameters of Shrimp Immersed in Seawater Containing G. tenuistipitata Extract (GTE)} Prior to and after Ammonia Stressing

Prior to the ammonia stress test, immune parameters increased directly with concentration of GTE. The levels of HC, GC, and THC of shrimp immersed in seawater containing $400 \mathrm{mg} / \mathrm{L}$ GTE increased by $38 \%, 33 \%$, and $37 \%$, respectively. PO activity, RB, SOD activity, lysozyme activity, and hemolymph protein level of shrimp immersed in $400 \mathrm{mg} / \mathrm{L}$ GTE increased significantly by 43\%, 39\%, $47 \%, 79 \%$, and $36 \%$, respectively (Figures $1-3$ ).

All shrimp in the three ammonia test treatments were still alive after $120 \mathrm{~h}$. Hemocyte counts and other immune parameters from the three treatments decreased with exposure time after 24-72 $\mathrm{h}$ but increased after $96 \mathrm{~h}$ and $120 \mathrm{~h}$. HC, GC, and THC from shrimp immersed in $600 \mathrm{mg} / \mathrm{L}$ GTE returned to their original values after $120 \mathrm{~h}$. However, HC, GC, and THC from control shrimp did not return to background values after $120 \mathrm{~h}$ (Figure 1).

In the ammonia stress test, PO activity, RB, and SOD activity of shrimp immersed in seawater containing $600 \mathrm{mg} / \mathrm{L}$ GTE returned to their original values by $120 \mathrm{~h}, 96 \mathrm{~h}$, and $120 \mathrm{~h}$, respectively. RB and SOD activity of shrimp immersed in $400 \mathrm{mg} / \mathrm{L}$ GTE both returned to their original values by 120 h. However, PO activity, RB, and SOD activity of control shrimp did not return to their original 
values after $120 \mathrm{~h}$ (Figure 2). In the ammonia stress test, lysozyme activity and hemolymph protein levels of shrimp immersed in $600 \mathrm{mg} / \mathrm{L}$ GTE returned to their original values at $96 \mathrm{~h}$ and $120 \mathrm{~h}$, respectively. However, lysozyme activity and hemolymph protein levels of control shrimp did not return to original values after $120 \mathrm{~h}$ (Figure 3).
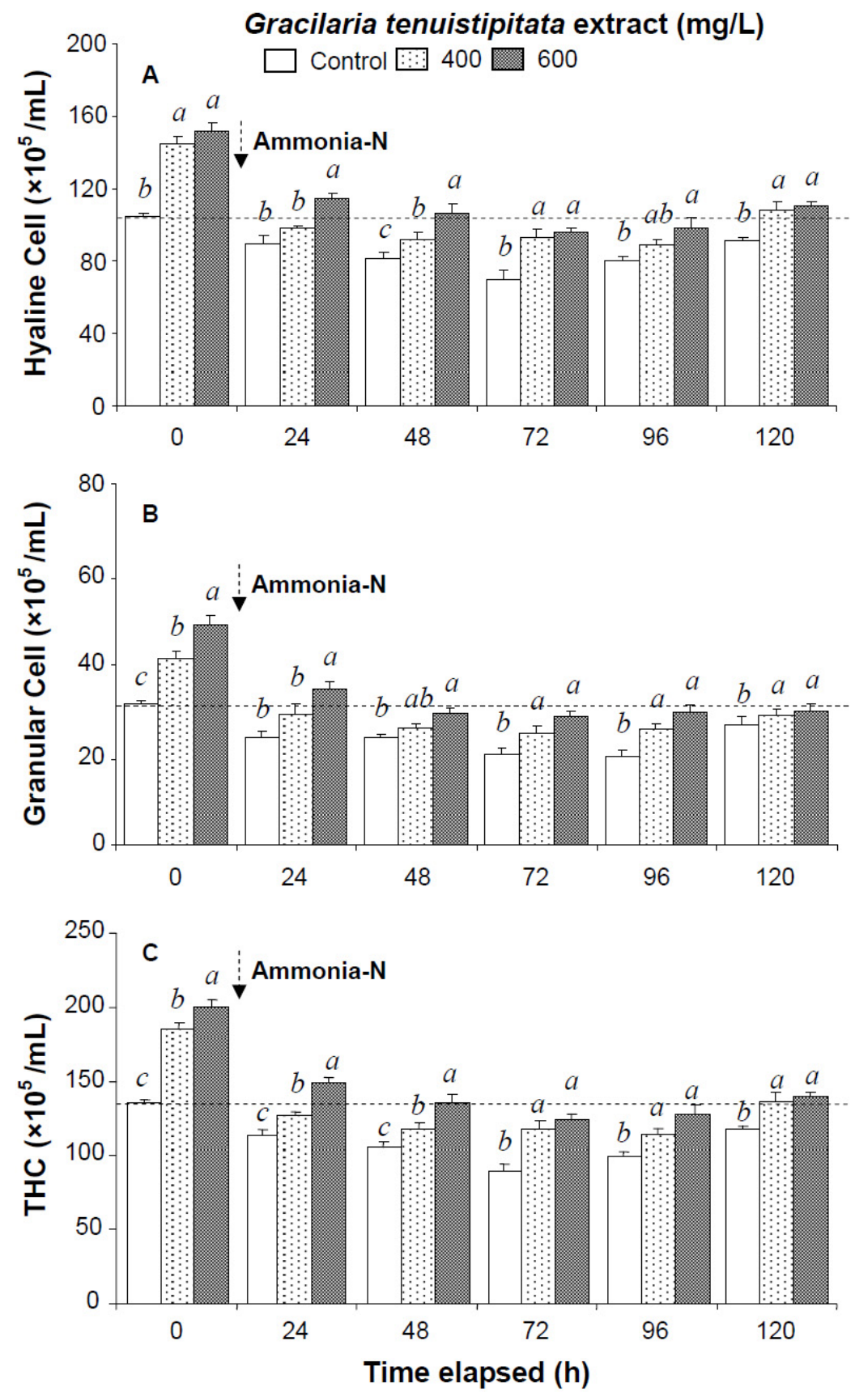

Figure 1. (A) Hyaline cells; (B) granular cells (including semi-granular cells); and (C) total hemocyte count (THC) of white shrimp Litopenaeus vannamei immersed in seawater containing Gracilaria tenuistipitata extract at 0 (control), 400, and $600 \mathrm{mg} / \mathrm{L}$ for $3 \mathrm{~h}$ and then exposed to $5 \mathrm{mg} / \mathrm{L}$ ammonia-N for 24, 48, 72, 96, and $120 \mathrm{~h}$. Each bar represents the mean value from eight determinations with the standard error (SE). Data (mean $\pm \mathrm{SE}$ ) with different letters are significantly different $(p<0.05)$ among treatments. 

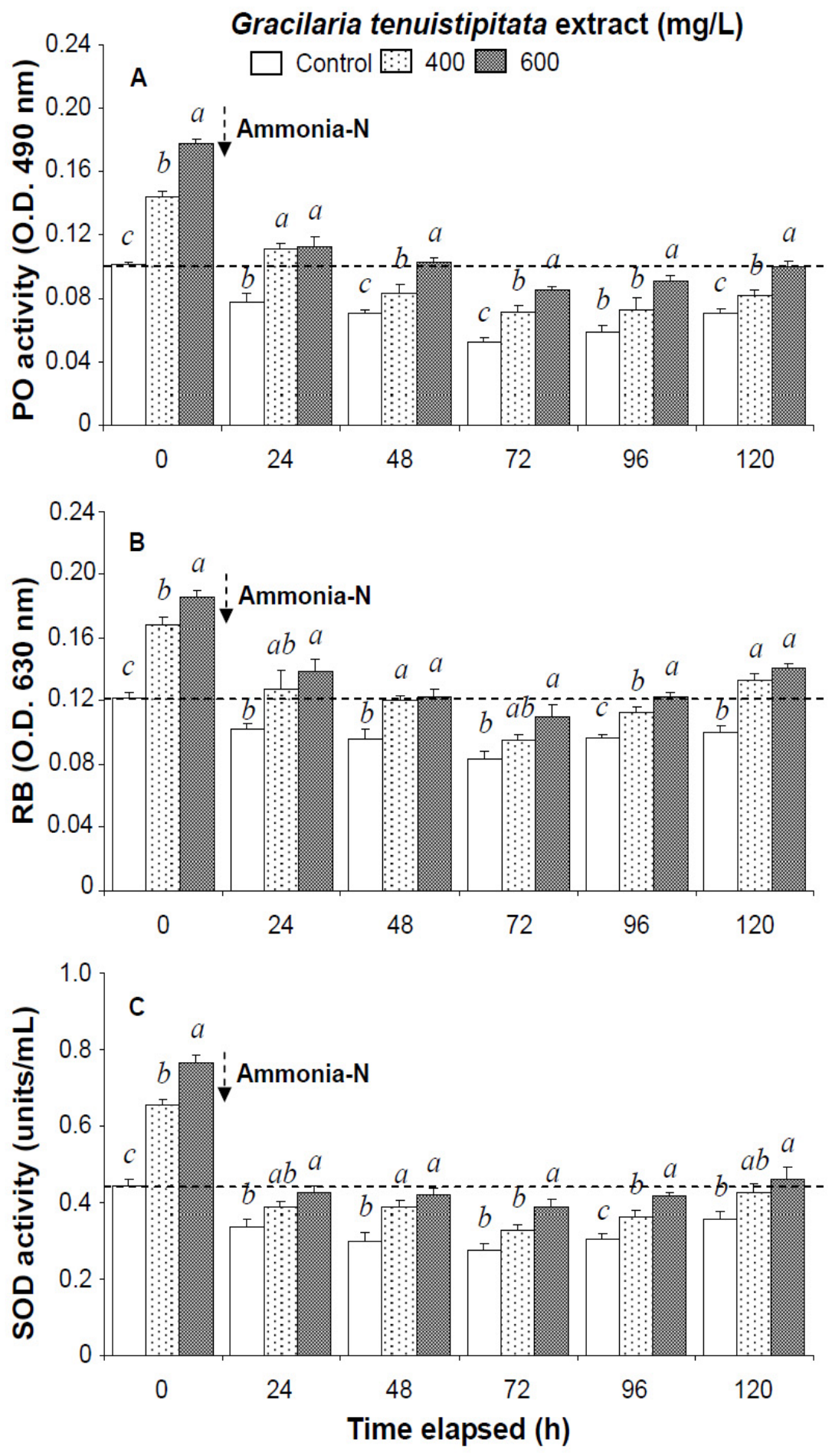

Figure 2. (A) Phenoloxidase activity; (B) respiratory burst (RB); and (C) superoxide dismutase (SOD) activity of white shrimp Litopenaeus vannamei immersed in seawater containing Gracilaria tenuistipitata extract at 0 (control), 400, and $600 \mathrm{mg} / \mathrm{L}$ for $3 \mathrm{~h}$ and then exposed to $5 \mathrm{mg} / \mathrm{L}$ ammonia-N for $24,48,72,96$, and $120 \mathrm{~h}$. Data (mean $\pm \mathrm{SE}$ ) with different letters are significantly different $(p<0.05)$ among treatments 

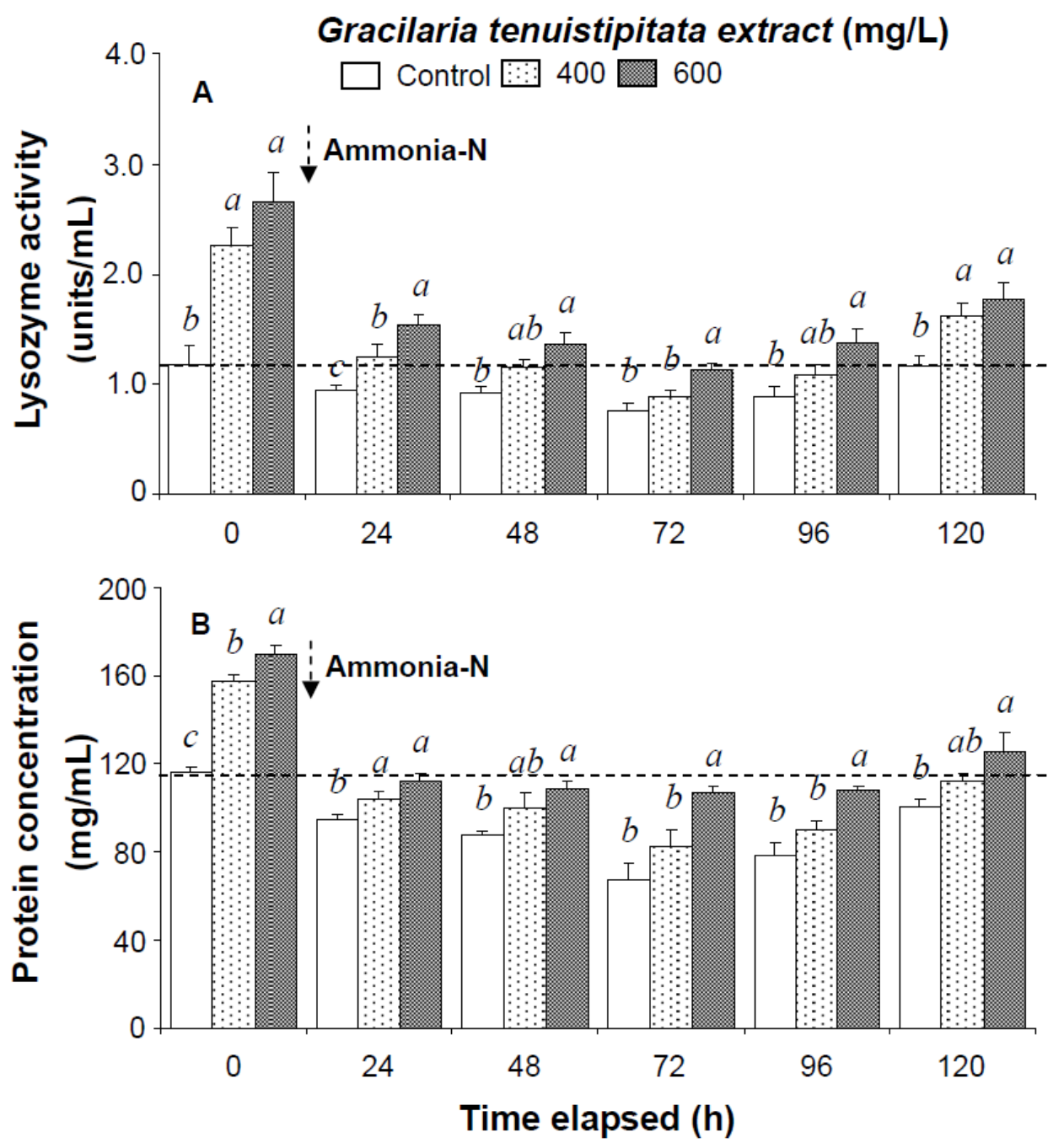

Figure 3. (A) Lysozyme activity and (B) hemolymph protein level of white shrimp Litopenaeus vannamei immersed in seawater containing Gracilaria tenuistipitata extract at 0 (control), 400, and $600 \mathrm{mg} / \mathrm{L}$ for $3 \mathrm{~h}$ and then exposed to $5 \mathrm{mg} / \mathrm{L}$ ammonia-N for 24,48 , 72, 96, and $120 \mathrm{~h}$. Data (mean $\pm \mathrm{SE}$ ) with different letters are significantly different $(p<0.05)$ among treatments.

2.2. Transcript Levels of $L G B P, P X, I B, p p A$, proPO I, proPO II, $\alpha 2-M$, cytMnSOD, $m t M n S O D$, ecCuZnSOD, and HSP70 in Shrimp Immersed in Seawater Containing G. tenuistipitata Extract (GTE) Prior to and after Ammonia Stressing

Prior to the ammonia stress test, IB and $\alpha 2-\mathrm{M}$ transcript levels of shrimp immersed in seawater containing $600 \mathrm{mg} / \mathrm{L}$ GTE were significantly up-regulated $(p<0.05)$. Transcript levels of LGBP, PX, proPOI, proPO II, and $\alpha 2-\mathrm{M}$ of shrimp immersed in $600 \mathrm{mg} / \mathrm{L}$ GTE increased but were not significantly different $(p>0.05)$ from control shrimp (Figures 4 and 5). In the ammonia stress test, LGBP and PX transcript levels of shrimp immersed in $600 \mathrm{mg} / \mathrm{L}$ GTE were significantly $(p<0.05)$ higher than in control shrimp after $24 \mathrm{~h}$. The transcript levels of IB, ppA, proPO I, proPO II, and $\alpha 2-\mathrm{M}$ of shrimp immersed in $600 \mathrm{mg} / \mathrm{L}$ GTE increased but were not significantly different $(p>0.05)$ from control shrimp after $24 \mathrm{~h}$ of post-ammonia stressing (Figures 4 and 5). 

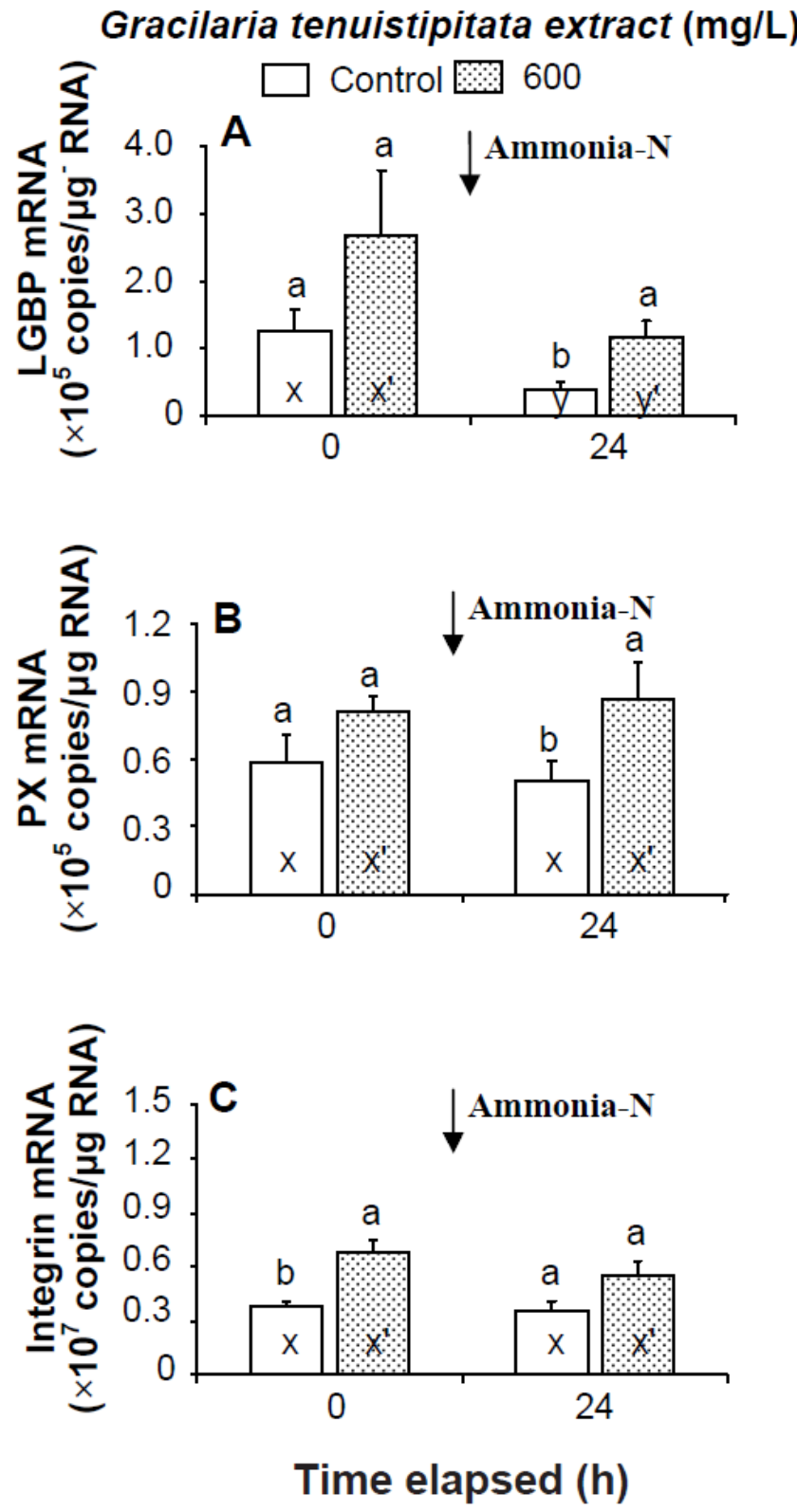

Figure 4. Transcript levels of (A) lipopolysaccharide and $\beta$-1,3-glucan binding protein (LGBP); (B) peroxinectin (PX); and (C) integrin $\beta$ (IB) of hemocytes of white shrimp Litopenaeus vannamei immersed in seawater containing Gracilaria tenuistipitata extract (GTE) at 0 (control) and $600 \mathrm{mg} / \mathrm{L}$ for $3 \mathrm{~h}$ and then exposed to seawater containing $5 \mathrm{mg} / \mathrm{L}$ ammonia-N for $24 \mathrm{~h}$. Each bar represents the mean value from eight determinations with the standard error $(\mathrm{SE})$. Data (mean $\pm \mathrm{SE}$ ) with different letters $(\mathrm{a}, \mathrm{b})$ are significantly different $(p<0.05)$ between treatments. Data with different letters $(\mathrm{x}, \mathrm{y})$ and with different letters $\left(\mathrm{x}^{\prime}, \mathrm{y}^{\prime}\right)$ are significantly different $(p<0.05)$ before and after ammonia stress between control shrimp and between GTE receiving shrimp. 

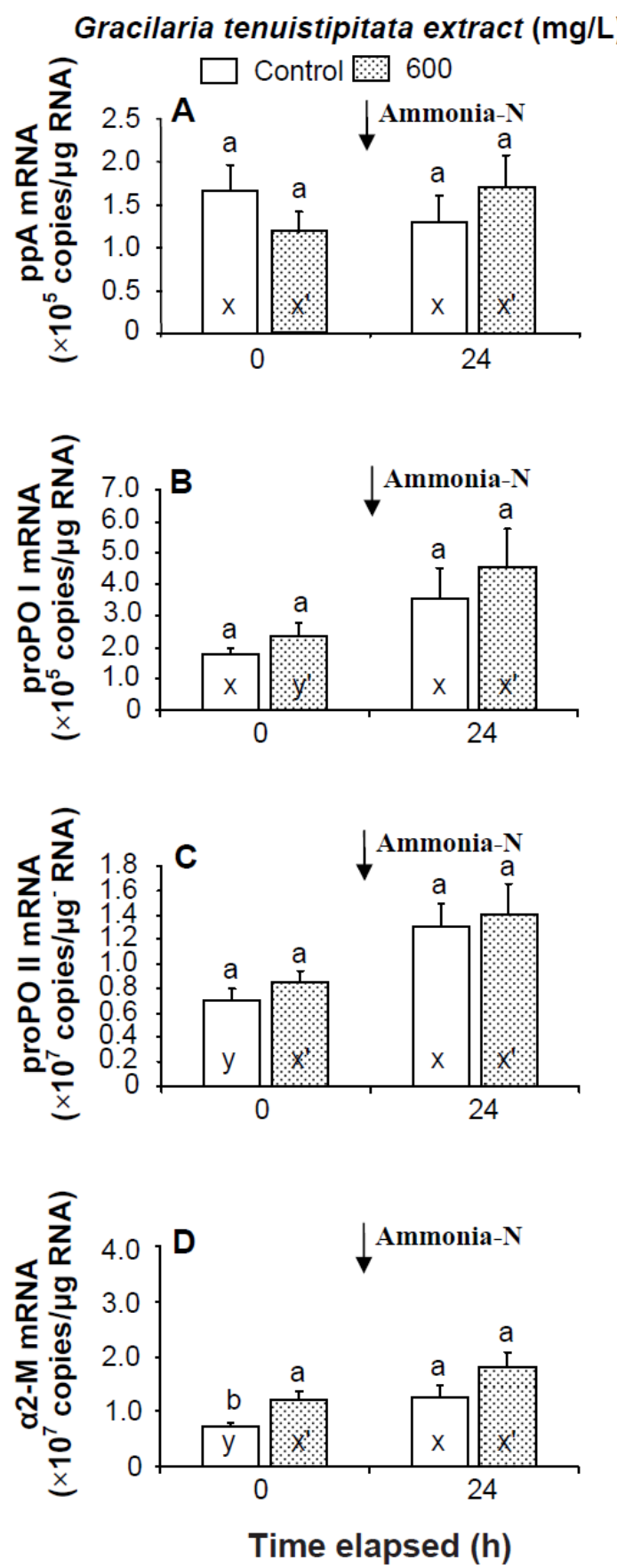

Figure 5. Transcript levels of (A) prophenoloxidase activating enzyme (ppA); (B) prophenoloxidase I (proPO I); (C) proPO II; and (D) $\alpha 2$-macroglobulin ( $\alpha 2-\mathrm{M}$ ) of hemocytes of white shrimp Litopenaeus vannamei immersed in seawater containing Gracilaria tenuistipitata extract at 0 (control) and $600 \mathrm{mg} / \mathrm{L}$ for $3 \mathrm{~h}$ and then exposed to seawater containing $5 \mathrm{mg} / \mathrm{L}$ ammonia-N for $24 \mathrm{~h}$. Data with different letters (x, y) and with different letters $\left(\mathrm{x}^{\prime}, \mathrm{y}^{\prime}\right)$ are significantly different $(p<0.05)$ before and after ammonia stress between control shrimp and between GTE receiving shrimp.

Prior to the ammonia stress test, the transcript level of mtMnSOD of shrimp immersed in seawater containing $600 \mathrm{mg} / \mathrm{L}$ GTE was significantly up-regulated $(p<0.05)$. The transcript levels of cytMnSOD, ecCuZnSOD, and HSP70 of shrimp immersed in $600 \mathrm{mg} / \mathrm{L}$ GTE were up-regulated but 
not significantly different $(p>0.05)$ from control shrimp. In the ammonia stress test, the transcript levels of cytMnSOD, mtMnSOD, and HSP70 were significantly higher $(p<0.05)$ in shrimp immersed in $600 \mathrm{mg} / \mathrm{L}$ GTE than in control shrimp after $24 \mathrm{~h}$. The transcript level of ecCuZnSOD of shrimp immersed in $600 \mathrm{mg} / \mathrm{L} \mathrm{GTE}$ was up-regulated but not significantly different $(p>0.05)$ from control shrimp following ammonia stressing (Figure 6).
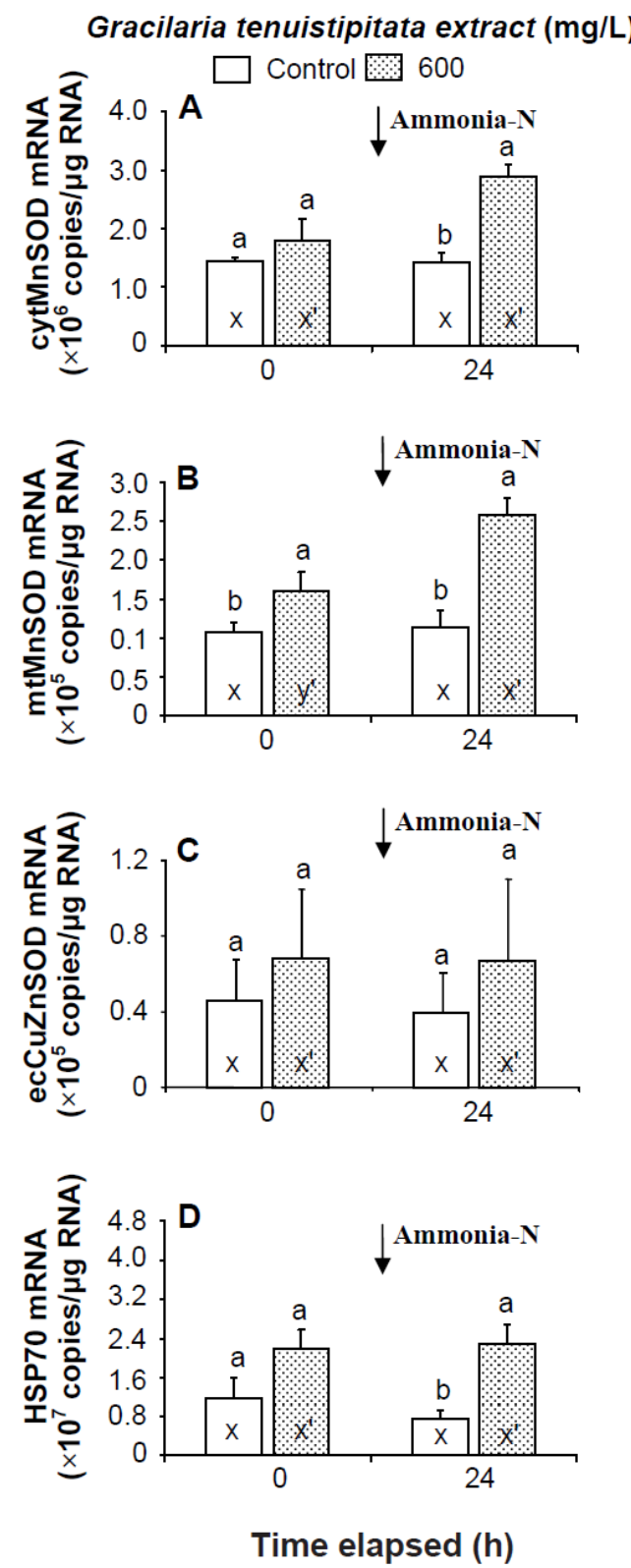

Figure 6. Transcript levels of (A) cytosolic manganese superoxide dismutase (cytMnSOD), (B) mitochondrial manganese superoxide dismutase (mtMnSOD), (C) extracellular copper-zinc superoxide dismutase (ecCuZnSOD), and (D) heat shock protein 70 (HSP70) of hemocytes of white shrimp Litopenaeus vannamei immersed in seawater containing Gracilaria tenuistipitata extract at 0 (control) and $600 \mathrm{mg} / \mathrm{L}$ for $3 \mathrm{~h}$ and then exposed to seawater containing $5 \mathrm{mg} / \mathrm{L}$ ammonia-N for $24 \mathrm{~h}$. Data with different letters (x, y) and with different letters $\left(\mathrm{x}^{\prime}, \mathrm{y}^{\prime}\right)$ are significantly different $(p<0.05)$ before and after ammonia stress between control shrimp and between GTE receiving shrimp. 


\section{Discussion}

The mortality of white shrimp L. vannamei subjected to combined stressing from a $V$. alginolytcius challenge and ammonia exposure is much higher than in shrimp subjected to ammonia alone [28]. White shrimp exposed to ammonia and then receiving a $V$. alginolyticus challenge show decreased phagocytic activity and clearance efficiency compared to controls [28]. Phagocytic and antibacterial activity in the swimming crab Portunus trituberculatus exposed to 1 and $5 \mathrm{mg} / \mathrm{L}$ ammonia-N decreased after $6 \mathrm{~h}$ [35]. Therefore, shrimp and crabs show decreased resistance against pathogens in the presence of ammonia in water.

In the present study, the immune parameters including hemocyte counts, PO activity, RB, and SOD activity significantly increased in shrimp that immersed in seawater containing GTE after $3 \mathrm{~h}$. Several scientists indicated that shrimp hemocytes incubated with $\beta G$, fucoidan, and carrageenan exhibit degranulation of granules, changes in cell size and viability, and increased PO activity and RB [36-38]. White shrimp that received carrageenan via immersion showed increased hemocyte count, and higher number of mitotic cells in the hematopoietic tissue (HPT) [36]. We conjecture that GTE like its analogue, carrageenan not only cause degranulate hemocytes but also induces hemocyte death that results in hematopoiesis.

The immune parameters decreased in shrimp following environmental stressing. For instance, the hemocyte count of blue shrimp Litopenaeus stylirostris exposed to 1.5 and $3.0 \mathrm{mg} / \mathrm{L}$ ammonia-N decreased by $15 \%$ and $50 \%$, respectively after $12 \mathrm{~h}$ [39]. The THC of the swimming crab exposed to $1 \mathrm{mg} / \mathrm{L}$ ammonia-N decreased after $6 \mathrm{~h}$ [35]. The PO activity of white shrimp exposed to $5.24 \mathrm{mg} / \mathrm{L}$ ammonia-N decreased significantly $(p<0.05)$ after $168 \mathrm{~h}$ [28]. In the present study, immune parameters (hemocyte count, PO activity, RB, SOD activity, and lysozyme activity) of control shrimp exposed to $5 \mathrm{mg} / \mathrm{L}$ ammonia-N significantly decreased $(p<0.05)$ earlier (after $24 \mathrm{~h}$ ), whereas the immune parameters of shrimp that immersed in seawater containing GTE at $600 \mathrm{mg} / \mathrm{L}$ decreased later (after $72 \mathrm{~h}$ ) at post ammonia stress. Therefore, shrimp that received GTE showed late decrease and earlier recovery in immune parameters compared to their original values indicating a protective immune response against ammonia stressing.

The immune parameters of shrimp that immersed in seawater containing GTE and then subjected to salinity stress (from $35 \%$ to $25 \%$ ) returned to their original values earlier than did those of control shrimp that subjected to salinity stressing [32]. The immune parameters of shrimp that immersed in seawater containing GTE and then subjected to temperature stressing (from $24{ }^{\circ} \mathrm{C}$ to $28{ }^{\circ} \mathrm{C}$ ) returned to their original values much earlier than did those of control shrimp that subjected to temperature stress [33]. The immune parameters of shrimp that fed a diet containing GTE at $0.5 \mathrm{~g} / \mathrm{kg}$, and then subjected to ammonia stressing returned to their original values earlier than did those of control shrimp and then subjected to ammonia stressing [40]. In the present study, the immune parameters of shrimp that received $600 \mathrm{mg} / \mathrm{L}$ GTE via immersion returned to their original values earlier than did those of control shrimp after ammonia stressing. We suggest that shrimp immersed in seawater containing the GTE show protective immunity or an immunity buffering effect on proPO activation system and phagocytosis system [4]. Shrimp that received GTE showed a capability for positive regulation by an earlier recovery of immune parameters in maintaining homeostasis. 
Antioxidant enzymes are known to play an important role in shrimp defense by scavenging the superoxide anion and other ROS [41]. In the present study, SOD activity in shrimp that received GTE was significantly higher than in control shrimp prior to ammonia stressing and at $24 \sim 120 \mathrm{~h}$ post-stress. The mtMnSOD transcript level of shrimp that received GTE was up-regulated. The cytMnSOD and mtMnSOD transcript levels of shrimp that received GTE were up-regulated at $24 \mathrm{~h}$ post-stress. Therefore, shrimp that received GTE showed an anti-oxidant capability against oxidative stress induced by ammonia.

Transcript levels of immune-related genes are affected in shrimp injected with foreign particles. For instance, the LGBP transcript in the hemocytes of kuruma shrimp Marsupenaeus japonicus is up-regulated within 12 72 h after being injected with LPS [7]. The LGBP transcript in the hemocytes of white shrimp is up-regulated within $12 \mathrm{~h}$ after being injected with $V$. alginolyticus [6]. The PX transcript in the hemocytes of white shrimp is up-regulated within $6 \sim 24 \mathrm{~h}$ after being injected with $V$. alginolyticus [42]. The LGBP transcript of white shrimp fed a diet containing $\beta G$ is up-regulated within $72 \mathrm{~h}$ post-feeding $[43,44]$. The transcripts of LGBP, IB, PX, ppA, propO I, proPO II, and $\alpha 2-\mathrm{M}$ are up-regulated in shrimp receiving a diet containing carrageenan at $0.5 \mathrm{~g} / \mathrm{kg}$ after 3 weeks [36]. LGBP contains two potential polysaccharide recognition motifs (polysaccharide binding motif and $\beta$-glucan recognition motif) and is known to bind to microbes and transmit signals to hemocytes through cell surface receptors [5,7]. Recent evidence strongly implies that recombinant LGBP binds with LPS and $\beta$-glucan, and subsequently leading to an increase PO activity in tiger shrimp $P$. monodon [44]. In a preliminary study, we also found that LGBP can bind with GTE and that PO activity increased in shrimp hemocytes treated with LGBP-GTE mixture [45].

The transcript levels of immune-related shrimp genes are affected by environmental stresses. For instance, the PX transcript of white shrimp subjected to higher temperature stress (raised to $32{ }^{\circ} \mathrm{C}$ from $26{ }^{\circ} \mathrm{C}$ ) was reduced after two days [12]. The LGBP and $\alpha 2-\mathrm{M}$ transcripts of white shrimp subjected to salinity stress (lowered to 25\% from 35\%o) were up-regulated after 24 and $12 \mathrm{~h}$, respectively [32]. The LGBP, PX and IB transcripts of white shrimp subjected to $\mathrm{pH}$ stress (lowered to $\mathrm{pH} 6.8$ from $\mathrm{pH}$ 8.2) are down-regulated after $24 \mathrm{~h}$ [46]. The transcript of HSP70, a stress-related gene, is up-regulated in tiger shrimp P. monodon after heat shock treatment (raised from $26{ }^{\circ} \mathrm{C}$ to $37{ }^{\circ} \mathrm{C}$ ) [47]. Crustin, anti-lipopolysaccharide factor (ALF), and lysozyme expressions are down-regulated in the swimming crab after exposure to $20 \mathrm{mg} / \mathrm{L}$ ammonia- $\mathrm{N}$, whereas $\alpha 2-\mathrm{M}$ expression is up-regulated after $6 \mathrm{~h}$ [35]. In the present study, LGBP expression was down-regulated, whereas proPO II and $\alpha 2-\mathrm{M}$ expressions were up-regulated in control shrimp exposed to ammonia. We suggest that exposing white shrimp to ammonia may decrease the expressions of antimicrobial peptides like ALF, crustin, lysozyme, and penaeidin.

LGBP, PX, and $\alpha 2-\mathrm{M}$ transcripts of shrimp immersed in seawater at $35 \%$ o salinity containing $600 \mathrm{mg} / \mathrm{L}$ GTE were up-regulated within $12 \mathrm{~h}$ after stressing with $25 \%$ salinity [32]. LGBP, PX, and IB transcripts of shrimp immersed in seawater (35\%; $\mathrm{pH} 8.2$ ) containing S. platensis extract at $600 \mathrm{mg} / \mathrm{L}$ were up-regulated within 24 h, 6 h, and 24 h, respectively, post-stress at pH 6.8 [46]. PX has cell adhesion and is associated with IB in mediating the binding of hemocytes, PAMP, and PRP [4]. In the present study, shrimp receiving GTE showed increases in the expressions of LGB, PX, and HSP70 after ammonia stressing. This suggests that the LGBP-GTE complex may transfer a signal to hemocytes and enhance LGBP synthesis in shrimp receiving GTE that are then subjected to ammonia 
stressing. Further research is needed to identify the recognition and binding of LGBP with GTE or its analogue like carrageenan in shrimp prior to and after ammonia stressing.

In conclusion, white shrimp L. vannamei immersed in seawater containing G. lenuistipitata extract that contains galactose-polymer as main effective molecules were capable of maintaining immune homeostasis as evidenced by earlier recovery in immune parameters and up-regulated transcript levels of LGBP, PX, cytMnSOD, mtMnSOD, and HSP70 while under ammonia stressing.

\section{Materials and Methods}

\subsection{Preparation of G. tenuistipitata Extract (GTE)}

Gracilaria tenuistipitata was collected from an algae farm in southern Taiwan. The preparation of the extract was followed the previously described procedures [31]. The GTE contains $11.72 \%$ crude protein, $0.49 \%$ crude lipid, $42.75 \%$ ash, and $45.04 \%$ carbohydrate (nitrogen free extract and crude fiber). GTE galacton content as quantified for galactose by the phenol-sulfuric acid method and sulfate content as measured by the gelatin-barium chloride turbidimetric method are $50.7 \%$ and $11 \%$, respectively $[48,49]$. The main polysaccharide components are galactose $(60.0 \%)$, fucose $(35.0 \%)$, fructose $(3.3 \%)$, and glucose $(1.8 \%)$ based on gas chromatographic-mass spectroscopic (GC-MS) analysis after hydrolytic reduction and acetylation of sugars [50,51].

\subsection{Experimental Design for the Immersion Test}

White shrimp L. vannamei obtained from the University Animal Center were shipped to the laboratory, and acclimated in fiberglass tanks having sand bed air lifts providing constantly aerated water and quarantined for two weeks prior to the experiments. Average shrimp weight was $11.2 \pm 0.6 \mathrm{~g}$ (mean $\pm \mathrm{SD}$ ) with no significant size differences among treatments. Only shrimp in the intermoult stage were used in this study [52]. Two studies were conducted, the first to examine immune parameters and transcript levels of immune-related genes after shrimp were immersed in seawater containing GTE and the second to examine immune parameters and transcript levels of immune-related genes after shrimp were immersed in seawater containing GTE and then ammonia stressed. The first study tested the shrimp prior to ammonia stressing and the second tested them after ammonia stressing. Water temperatures during experimental periods ranged $27-28{ }^{\circ} \mathrm{C}, \mathrm{pH} 7.9-8.1$, salinity $35 \%$, and dissolved oxygen (DO) $5.63-6.72 \mathrm{mg} / \mathrm{L}$. In addition, shrimp that received no GTE and no ammonia exposure served as control.

\subsection{Immune Parameters of Shrimp Immersed in Seawater Containing G. tenuistipitata Extract (GTE)} Prior to and after Ammonia Stressing

White shrimp that had been immersed in seawater containing GTE for $3 \mathrm{~h}$ were then exposed to $5 \mathrm{mg} / \mathrm{L}$ ammonia-N. There were three GTE solutions $(0,400$, and $600 \mathrm{mg} / \mathrm{L})$ with one exposure time $(3 \mathrm{~h})$ prior to stress, and three solutions of $\operatorname{GTE}(0,400$, and $600 \mathrm{mg} / \mathrm{L})$ with five exposure times $(24,48,72,96$, and $120 \mathrm{~h})$ in the ammonia stress test. Prior to the ammonia stress test, 10 shrimp that had been immersed in each test solution $(20 \mathrm{~L})$ for $3 \mathrm{~h}$ were sampled. Therefore, there were three treatments, and 30 shrimp $(10 \times 3)$ in total were used for the study prior to the ammonia stress test. In 
the ammonia stress test, 50 shrimp immersed in each test solution for $3 \mathrm{~h}$ were sampled and then exposed to $5 \mathrm{mg} / \mathrm{L}$ ammonia-N. Ten shrimp were used in each test solution and each exposure time. Therefore, there were 15 treatments, and 150 shrimp $(10 \times 3 \times 5)$ in total were used for the ammonia stress test. The concentration of ammonia-N test solution $(5 \mathrm{mg} / \mathrm{L})$ was determined based on one eighth of the 96-h median lethal concentration (LC50) (39.54 mg/L) of ammonia-N on white shrimp juveniles at $35 \%$ and $23{ }^{\circ} \mathrm{C}[25]$. The test water solution $(5 \mathrm{mg} / \mathrm{L})$ was renewed daily.

\subsection{Measurements of Immune Parameters}

At $3 \mathrm{~h}$ prior to the ammonia stress test, and after 24, 48, 72, 96, and $120 \mathrm{~h}$ in the ammonia stress test, eight shrimp from each tank were sampled individually. Sampling of hemolymph, preparation of anticoagulant-hemolymph mixture, and hemocyte counts followed the procedures previously described [32]. Briefly, hemolymph $(300 \mu \mathrm{L})$ was individually withdrawn from the ventral sinus of each shrimp using a 1-mL sterile syringe with a 25 gauge needle, diluted with $2700 \mu \mathrm{L}$ of an anticoagulant solution $(30 \mathrm{mM}$ trisodium citrate, $340 \mathrm{mM}$ sodium chloride, and $10 \mathrm{mM}$ EDTA at $\mathrm{pH} 7.55$, with osmolality adjusted to $718 \mathrm{mOsm} / \mathrm{kg}$ by the addition of $115 \mathrm{mM}$ glucose). The hemolymph-anticoagulant mixture was placed in four tubes. Each tube contained 500, 1000, 1000, and $500 \mu \mathrm{L}$ of the hemolymph mixture, and was used to measure (1) hemocyte count, RB, and hemolymph protein concentration; (2) PO activity; (3) SOD activity; and (4) lysozyme activity, respectively [32]. Hyaline cells and granular cells can be identified based on their size and degree of granularity [2].

PO activity was measured spectrophotometrically by recording the formation of dopachrome produced from L-dihydroxyphenylalanine (L-DOPA) [30,53,54]. Hemocyte RB was quantified by measuring the intracellular production of the superoxide anion using the reduction of nitroblue tetrazolium (NBT) to formazan [30,55]. SOD activity was measured by its ability to inhibit superoxide radical-dependent reactions using a Ransod Kit (Randox, Crumlin, UK) [32,56]. Lysozyme activity was determined following a previously described method [57-59]. Hemolymph protein level was quantified with a Bio-Rad protein assay kit no. 500-0006 (Bio-Rad Laboratories, Richmond, CA, USA) with bovine serum albumin (molecular weight: $66 \mathrm{kDa}$ ) as a standard [60,61].

\subsection{Transcript Levels of LGBP, PX, IB, ppA, proPO I, proPO II, $\alpha 2-M$, cytMnSOD, $m t M n S O D$, ecCuZnSOD, and HSP70 in Shrimp Immersed in Seawater Containing G. tenuistipitata Extract (GTE)} Prior to and after Ammonia Stressing

There were two solutions of GTE ( 0 and $600 \mathrm{mg} / \mathrm{L})$ with one exposure time $(3 \mathrm{~h})$ prior to the ammonia stress and two GTE solutions ( 0 and $600 \mathrm{mg} / \mathrm{L})$ with one exposure time $(24 \mathrm{~h})$ after the ammonia stress. Eight shrimp from each concentration and exposure time were sampled for gene expression assays. There were a total of 4 treatments and 32 shrimp $[(8 \times 2 \times 1)+(8 \times 2 \times 1)]$ used in the study.

Hemolymph $(500 \mu \mathrm{L})$ was individually withdrawn as described above, placed in a tube containing $500 \mu \mathrm{L}$ of an anticoagulant solution, and centrifuged at $800 \times g$ and $4{ }^{\circ} \mathrm{C}$ for $20 \mathrm{~min}$. The isolation of total RNA from hemocytes, design of primer sets for each gene expression, and quantification of target genes LGBP, PX, IB, ppA, proPO I, proPO II, $\alpha 2-\mathrm{M}$, cytMnSOD, mtMnSOD, ecCuZnSOD, and HSP70, and the internal control (EF1 $\alpha$ ) were measured with qPCR [62]. Primer sets for each gene 
were designed based on the available genes of white shrimp using Beacon Designer Software vers. 6.0 (Table 1).

Table 1. Primers used for the quantitative real-time PCR study of elongation factor 1-alpha (EF $1 \alpha)$ and eleven immune-related genes of the white shrimp Litopenaeus vannamei.

\begin{tabular}{|c|c|c|c|c|}
\hline Gene & Primer Name & Sequence $5^{\prime}$ to $3^{\prime}$ & Amplicon & $\begin{array}{r}\text { Reference/ } \\
\text { GenBank }\end{array}$ \\
\hline$L G B P$ & $\begin{array}{l}\text { Liva LGBP qPCR F } \\
\text { Liva LGBP qPCR R }\end{array}$ & $\begin{array}{l}\text { CGG CAA CCA GTA CGG AGG AAC } \\
\text { GTG GAA ATC ATC GGC GAA GGA G }\end{array}$ & $115 \mathrm{bp}$ & EU102286 \\
\hline Peroxinectin & $\begin{array}{l}\text { Liva PX qPCR F } \\
\text { Liva PX qPCR R }\end{array}$ & $\begin{array}{l}\text { ATC CAG CAG CCA GGT ATG } \\
\text { CAG ACT CAT CAG ATC CAT TCC }\end{array}$ & $147 \mathrm{bp}$ & {$[12]$} \\
\hline Integrin $\beta$ & $\begin{array}{l}\text { Liva It } \beta \text { qPCR F } \\
\text { Liva It } \beta \text { qPCR R }\end{array}$ & $\begin{array}{l}\text { TTG GGC ATC GTG TTC GGA CTC } \\
\text { TGA AGG TGT TGG TCG CAG GTC }\end{array}$ & $184 \mathrm{bp}$ & GQ889365 \\
\hline$p p A$ & $\begin{array}{l}\text { Liva ppA qPCR F } \\
\text { Liva ppA qPCR R }\end{array}$ & $\begin{array}{l}\text { CTA GAG ACG TCG GTG TCA TCA CC } \\
\text { AAC TTG CCG TCC GAA GTG CG }\end{array}$ & $151 \mathrm{bp}$ & AY368151 \\
\hline proPO I & $\begin{array}{l}\text { Liva proPO I qPCR F } \\
\text { Liva proPO I qPCR R }\end{array}$ & $\begin{array}{l}\text { ACG TCA CTT CCG GCA AGC GA } \\
\text { CCT CCT TGT GAG CGT TGT CAG G }\end{array}$ & $156 \mathrm{bp}$ & AY723296 \\
\hline proPO II & $\begin{array}{l}\text { Liva proPO II qPCR F } \\
\text { Liva proPO II qPCR R }\end{array}$ & $\begin{array}{l}\text { ACC ACT GGC ACT GGC ACC TCG TCT A } \\
\text { TCG CCA GTT CTC GAG CTT CTG CAC }\end{array}$ & $161 \mathrm{bp}$ & EU373096 \\
\hline a2-macroglobulin & $\begin{array}{l}\text { Liva A2M qPCR F } \\
\text { Liva A2M qPCR R }\end{array}$ & $\begin{array}{l}\text { GCA CGT AAT CAA GAT CCG } \\
\text { CCC ATC TCA TTA GCA CAA AC }\end{array}$ & $204 \mathrm{bp}$ & DQ988330 \\
\hline cytMnSOD & $\begin{array}{l}\text { Liva cytMnSOD qPCR F } \\
\text { Liva cytMnSOD qPCR R }\end{array}$ & $\begin{array}{l}\text { TGA CGA GAG CTT TGG ATC ATT CC } \\
\text { TGA TTT GCA AGG GAT CCT GGT T }\end{array}$ & $155 \mathrm{bp}$ & DQ029053 \\
\hline$m t M n S O D$ & $\begin{array}{l}\text { Liva mtMnSOD qPCR F } \\
\text { Liva mtMnSOD qPCR R }\end{array}$ & $\begin{array}{l}\text { CAG ACT TGC CCT ACG ATT AC } \\
\text { AGA TGG TGT GAT TGA TGT GAC }\end{array}$ & $216 \mathrm{bp}$ & КР099968 \\
\hline ecCuZnSOD & $\begin{array}{l}\text { Liva CuZnSOD qPCR F } \\
\text { Liva CuZnSOD qPCR R }\end{array}$ & $\begin{array}{l}\text { CGC GGG AGA CAC AGC TGA TTT C } \\
\text { GAA ATC CAG GGT GCC GGA GA }\end{array}$ & $164 \mathrm{bp}$ & HM371157 \\
\hline HSP70 & $\begin{array}{l}\text { Liva Hsp70 qPCR F } \\
\text { Liva Hsp70 qPCR R }\end{array}$ & $\begin{array}{l}\text { CCT CCT ACG TCG CCT TCA CAG ACA } \\
\text { GGG GTA GAA GGT CTT CTT GTC TCC C }\end{array}$ & $233 \mathrm{bp}$ & AY645906 \\
\hline$E F 1 \alpha$ & $\begin{array}{l}\text { Liva EF } 1 \alpha \text { qPCR F } \\
\text { Liva EF } 1 \alpha \text { qPCR R }\end{array}$ & $\begin{array}{l}\text { ATG GTT GTC AAC TTT GCC CC } \\
\text { TTG ACC TCC TTG ATC ACA CC }\end{array}$ & $500 \mathrm{bp}$ & GU136229 \\
\hline
\end{tabular}

\subsection{Statistical Analysis}

All data were subjected to a one-way analysis of variance (ANOVA). If significant differences were indicated at the 0.05 level, then Tukey's multiple-comparisons test was conducted to examine significant differences among treatments using SAS computer software (SAS Institute, Cary, NC, USA). Statistical significance of differences required that $p<0.05$.

\section{Acknowledgments}

This research was supported by a grant from the National Science Council (NSC 98-2313-B-019002-MY3), Taiwan, ROC, and received partial support from the Center of Excellence for the Ocean, National Taiwan Ocean University. 


\section{Author Contributions}

JCC conceived and designed the experiment; YYC, YCL, STY performed the experiments; YYC, CLH analyzed the data; JCC wrote the paper.

\section{Conflicts of Interest}

The authors declare no conflict of interest.

\section{References}

1. Carroll, M.C.; Janeway, C.A., Jr. Innate immune recognition: Mechanism and pathways. Immunol. Rev. 2000, 173, 89-97.

2. Rowley, A.F.; Powell, A. Invertebrate immune systems specific, quasi-specific, or nonspecific? J. Immunol. 2007, 179, 7209-7214.

3. Wang, X.W.; Wang, J.X. Pattern recognition receptors acting in innate immune system of shrimp against pathogen infections. Fish Shellfish Immunol. 2013, 34, 981-989.

4. Cerenius, L.; Lee, B.L.; Söderhäll, K. The proPO-system: Pros and cons for its role in invertebrate immunity. Trends Immunol. 2008, 29, 263-271.

5. Jiravanichpaisal, P.; Lee, B.L.; Söderhäll, K. Cell-mediated immunity in arthropods: Hematopoiesis, coagulation, melanization and opsonization. Immunobiology 2006, 211, 213-236.

6. Cheng, W.; Liu, C.H.; Tsai, C.T.; Chen, J.C. Molecular cloning and characterisation of a pattern recognition molecule, lipopolysaccharide- and $\beta$-1,3-glucan binding protein (LGBP) from the white shrimp Litopenaeus vannamei. Fish Shellfish Immunol. 2005, 18, 297-310.

7. Lin, Y.C.; Vaseeharan, B.; Chen, J.C. Identification and phylogenetic analysis on lipopolysaccharide and $\beta$-1,3-glucan binding protein (LGBP) of kuruma shrimp Marsupenaeus japonicus. Dev. Comp. Immunol. 2008, 32, 1260-1269.

8. Tassanakajon, A.; Somboonwiwat, K.; Supungul, P.; Tang, S. Discovery of immune molecules and their crucial functions in shrimp immunity. Fish Shellfish Immunol. 2013, 34, 954-967.

9. Cerenius, L.; Söderhäll, K. The prophenoloxidase-activating system in invertebrates. Immunol. Rev. 2004, 198, 116-126.

10. Liu, H.; Jiravanichpaisal, P.; Cerenius, L.; Söderhäll, I.; Söderhäll, K. Phenoloxidase is an important component of the defense against Aeromonas hydrophila infection in a crustacean, Pacifastacus leniusculus. J. Biol. Chem. 2007, 282, 33593-33598.

11. Amparyup, P.; Charoensapsri, W.; Tassanakajon, A. Prophenoloxidase system and its role in shrimp immune response against major pathogens. Fish Shellfish Immunol. 2013, 34, 990-1001.

12. Liu, C.H.; Cheng, W.; Kuo, C.M.; Chen, J.C. Molecular cloning and characterisation of a cell adhesion molecule, peroxinectin from the white shrimp Litopenaeus vannamei. Fish Shellfish Immunol. 2004, 17, 13-26.

13. Lin, Y.C.; Chen, J.C.; Chen, Y.Y.; Liu, C.H.; Cheng, W.; Hsu, C.H.; Tsui, W.C. Characterization of white shrimp Litopenaeus vannamei integrin $\beta$ and its role in immunomodulation by dsRNA-mediated gene silencing. Dev. Comp. Immunol. 2013, 40, 169-179. 
14. Bayne, C.J. Phagocytosis and non-self recognition in invertebrates-phagocytosis appears to be an ancient line of defense. Bioscience 1990, 40, 723-731.

15. Lin, Y.C.; Chen, J.C.; Morni, W.Z.; Putra, D.F.; Huang, C.L.; Li, C.C.; Hsieh, J.F. Vaccination enhances early immune responses in white shrimp Litopenaeus vannamei after secondary exposure to Vibrio alginolyticus. PLoS ONE 2013, 8, e69722.

16. Muñoz, M.; Cedeño, R.; Rodríguez, J.; van der Knapp, W.P.W.; Mialhe, E.; Bachère, E. Measurement of reactive oxygen intermediate production in haemocytes of the penaeid shrimp, Penaeus vannamei. Aquaculture 2000, 191, 89-107.

17. Fridovich, I. Superoxide radical and superoxide dismutase. Annu. Rev. Biochem. 1995, 64, 97-112.

18. Matés, J.M. Effects of antioxidant enzymes in the molecular control of reactive oxygen species toxicology. Toxicology 2000, 153, 83-104.

19. Gómez-Anduro, G.A.; Barillas-Mury, C.V.; Peregrino-Uriarte, A.B.; Gupta, L.; Gollas-Galván, T.; Hernández-López, J.; Yepiz-Plascencia, G. The cytosolic manganese superoxide dismutase from the shrimp Litopenaeus vannamei: Molecular cloning and expression. Dev. Comp. Immunol. 2006, 30, 893-900.

20. Tian, J.; Chen, J.; Jiang, D.; Liao, S.; Wang, A. Transcriptional regulation of extracellular copper zinc superoxide dismutase from white shrimp Litopenaeus vannamei following Vibrio alginolyticus and WSSV infection. Fish Shellfish Immunol. 2011, 30, 234-240.

21. Santacruz, H.; Vriz, S.; Angelier, N. Molecular characterization of a heat shock cognate cDNA of zeabrafish, hsc70, and developmental expression of the corresponding transcripts. Dev. Comp. Immunol. 1997, 21, 223-233.

22. FAO. 2011 FAO Yearbook. In Fishery and Aquaculture Statistics; Food and Agriculture Organization of the United Nations: Rome, Italy, 2003; p. 105.

23. Chen, J.C.; Liu, P.C.; Lin, Y.T. Super intensive culture of red-tailed shrimp Penaeus penicillatus. J. World Aquac. Soc. 1988, 19, 127-131

24. Chen, J.C.; Liu, P.C.; Lin, Y.T.; Lee, C.K. Highly intensive culture study of tiger prawn Penaeus monodon in Taiwan. In Aquaculture-A Biotechnology in Progress; de Pauw, D., Jaspers, E., Ackeforos, H., Wilkins, N., Eds.; European Aquaculture Society: Bredene, Belgium, 1989; pp. 377-382.

25. Lin, Y.C.; Chen, J.C. Acute toxicity of ammonia on Litopenaeus vannamei Boone juveniles at different salinity levels. J. Exp. Mar. Biol. Ecol. 2001, 259, 109-119.

26. Chen, J.C.; Lin, C.Y. Effects of ammonia on growth and molting of Penaeus monodon juveniles. Comp. Biochem. Physiol. C Comp. Pharmacol. 1992, 101, 449-452.

27. Chen, J.C.; Chen, C.T. Changes of osmotic and electrolyte concentrations in the haemolymph of Penaeus japonicus exposed to ambient ammonia. Comp. Biochem. Physiol. C Pharmacol. Toxicol. Endocrinol. 1996, 114, 35-38.

28. Liu, C.H.; Chen, J.C. Effect of ammonia on the immune response of white shrimp Litopenaeus vannamei and its susceptibility to Vibrio alginolyticus. Fish Shellfish Immunol. 2004, 16, 321-334.

29. Hou, W.Y.; Chen, J.C. The immunostimulatory effect of hot-water extract of Gracilaria tenuistipitata on the white shrimp Litopenaeus vannamei and its resistance against Vibrio alginolyticus. Fish Shellfish Immunol. 2005, 19, 127-138. 
30. Yeh, S.T.; Chen, J.C. White shrimp Litopenaeus vannamei that received the hot-water extract of Gracilaria teniustisitata showed earlier recovery in immunity after a Vibrio algnolyticus injection. Fish Shellfish Immunol. 2009, 26, 724-730.

31. Sirirustananun, N.; Chen, J.C.; Lin, Y.C.; Yeh, S.T.; Liou, C.H.; Sim, S.S.; Chiew, S.L. Dietary administration of a Gracilaria tenuistipitata extract enhances the immune response and resistance against Vibrio alginolyticus and white spot syndrome virus in the white shrimp Litopenaeus vannamei. Fish Shellfish Immunol. 2011, 31, 848-855.

32. Yeh, S.T.; Lin, Y.C.; Huang, C.L.; Chen, J.C. White shrimp Litopenaeus vannamei that received the hot-water extract of Gracilaria tenuistipitata showed protective innate immunity and up-regulation of gene expressions after low-salinity stress. Fish Shellfish Immunol. 2010, 28, 887-894.

33. Yeh, S.T.; Li, C.C.; Tsuei, W.J.; Chen, J.C. The protective immunity of white shrimp Litopenaeus vannamei that had been immersed in the hot-water extract of Gracilaria tenuistipitata and subjected to combined stresses of Vibrio alginolyticus injection and temperature change. Fish Shellfish Immunol. 2010, 29, 271-278.

34. Lin, Y.C.; Yeh, S.T.; Li, C.C.; Chen, L.L.; Cheng, A.C.; Chen, J.C. An immersion of Gracilaria tenuistipitata extract improves the immunity and survival of white shrimp Litopenaeus vannamei challenged with white spot syndrome virus. Fish Shellfish Immunol. 2011, $31,1239-1246$.

35. Yue, F.; Pan, L.; Xie, P.; Zheng, D.; Li, J. Immune response and expression of immune related genes in swimming crab Portunus trituberculatus exposed to elevated ambient ammonia-N stress. Comp. Biochem. Physiol. A Mol. Integr. Physiol. 2010, 157, 246-251.

36. Chen, Y.Y.; Chen, J.C.; Lin, Y.Y.; Putra, D.F.; Kitikiew, S.; Li, C.C.; Hsieh, J.F.; Liou, C.H.; Yeh, S.T. Shrimp that have received carrageenan via immersion and diet exhibit immunocompetence in phagocytois despite a post-plateau in immune parameters. Fish Shellfish Immunol. 2014, 36, 352-366.

37. Kitikiew, S.; Chen, J.C.; Putra, D.F.; Lin, Y.C.; Yeh, S.T.; Liou, C.H. Fucoidan effectively provokes the innate immunity of white shrimp Litopenaeus vannamei and its resistance against experimental Virio alginolyticus infection. Fish Shellfish Immunol. 2013, 34, 280-290.

38. Smith, V.J.; Söderhäll, K.; Hamiliton, M. $\beta-1,3-$ Glucan induced cellular defense reaction in the shore crab, Cracinus maenas. Comp. Biochem. Physiol. A Physiol. 1984, 77, 636-639.

39. Le Moullac, G.; Haffner, P. Environmental factors affecting immune responses in Crustacea. Aquaculture 2000, 191, 121-131.

40. Chen, Y.Y.; Sim, S.S.; Chiew, S.L.; Yeh, S.T.; Liou, C.H.; Chen, J.C. Dietary administration of a Gracilaria tenuistipitata extract produces protective immunity of white shrimp Litopenaeus vannamei in response to ammonia stress. Aquaculture 2012, 370-371, 26-31.

41. Yu, B.P. Cellular defenses against damage from reactive oxygen species. Physiol. Rev. 1994, 74, $139-162$.

42. Liu, C.H.; Cheng, W.; Chen, J.C. The peroxinectin of white shrimp Litopenaeus vannamei is synthesised in the semi-granular and granular cells, and its transcription is up-regulated with Vibrio alginolyticus infection. Fish Shellfish Immunol. 2005, 18, 431-444. 
43. Wang, Y.C.; Chang, P.S.; Chen, H.Y. Differential time-series expression of immune-related genes of Pacific white shrimp Litopenaeus vannamei in response to dietary inclusion of $\beta$-1,3-glucan. Fish Shellfish Immunol. 2008, 24, 113-121.

44. Amparyup, P.; Sutthangkul, J.; Charoensapsri, W.; Tassanakajon, A. Pattern recognition protein to lipopolysaccharide and $\beta$-1,3-glucan and activates shrimp prophenoloxidase system. $J$. Biol. Chem. 2012, 287, 10060-10069.

45. Chen, Y.Y.; Chen, J.C.; Kong, H.Y.; Kuo, Y.I.; Lin, Y.C.; Chang, Y.H.; Huang, C.H. Lipopolysaccharide and $\beta$-1,3-glucan binds to seaweed polysaccharide and activates prophenoloxidase system in white shrimp. 2015, Unpublished work.

46. Lin, Y.C.; Tayag, C.M.; Huang, C.L.; Tsui, W.C.; Chen, J.C. White shrimp Litopenaeus vannamei that had received the hot-water extract of Spirulina platensis showed earlier recovery in immunity and up-regulation of gene expressions after pH stress. Fish Shellfish Immunol. 2010, 29, 1092-1098.

47. Lo, W.Y.; Liu, K.F.; Liao, I.C.; Song, Y.L. Cloning and molecular characterization of heat shock cognate 70 from tiger shrimp (Penaeus monodon). Cell Stress Chaperones 2004, 9, 332-343.

48. Dubois, M.; Gilles, K.A.; Hamilton, J.K.; Rebers, F.; Smith, F. Colorimetric method for determination of sugars and related substances. Anal. Chem. 1956, 28, 350-356.

49. Terho, T.T.; Hartiala, K. Methods for determination of the sulfate content of glycosaminoglycans. Anal. Biochem. 1971, 41, 471-476.

50. Chao, K.P.; Su, Y.C.; Chen, S.C. Chemical composition and potential for utilization of the Rhizoclonium sp. J. Appl. Phycol. 1999, 11, 525-533.

51. Hayashi, T.; Hayashi, K. Calcium spirulina, an inhibitor of enveloped virus replication, from a blue green alga Spirulina platensis. J. Nat. Prod. 1996, 59, 83-87.

52. Chan, S.M.; Rankin, S.M.; Keeley, L.L. Characterization of the molt stages in Penaeus vannamei: Setogenesis and hemolymph levels of total protein ecdysteroids, and glucose. Biol. Bull. 1988, 175, 85-192.

53. Söderhäll, K.; Unestam, T. Activation of serum prophenoloxidase in arthropod immunity: The specificity of cell wall glucan activation and activation by purified fungal glycoprotein of crayfish phenoloxidase. Can. J. Microbiol. 1979, 25, 406-414.

54. Hernández-López, J.; Gollas-Galván, T.; Vargas-Albores, F. Activation of the prophenoloxidase system of the brown shrimp (Penaeus californiensis Holmes). Comp. Biochem. Physiol. C Pharmacol. Toxicol. Endocrinol. 1996, 113, 61-66.

55. Bell, K.L.; Smith, V.J. In vitro superoxide production by hyaline cells of the shore crab Carcinus maenas (L.). Dev. Comp. Immunol. 1993, 17, 211-219.

56. Biagini, G.; Sala, D.; Zini, I. Diethyldithiocarbamate, a superoxide dismutase inhibitor, counteracts the maturation of ischemic-like lesions caused by endothelin-1 intrastriatal injection. Neurosci. Lett. 1995, 90, 212-216.

57. Soteo-Mundo, R.R.; Islas-Osuna, M.A.; de-la-Re-Vega, E.; Hernández-López, J.; Vargas-Albores, F.; Yepiz-Plascencia, G. cDNA cloning of the lysozyme of the white shrimp Penaeus vannamei. Fish Shellfish Immunol. 2003, 15, 325-331.

58. Ellis, A.E. Lysozyme assay. In Technique in Fish Immunology-1; Stolen, J.S., Fletcher, T.C., Anderson, D.P., Roberson, B.S., van Muiswinkel, W.B., Eds.; SOS Publications: Fair Haven, NJ, USA, 1990; pp. 101-103. 
59. Tayag, C.M.; Lin, Y.C.; Li, C.C.; Liou, C.H.; Chen, J.C. Administration of the hot-water extract of Spirulina platensis enhanced the immune response of white shrimp Litopenaeus vannamei and its resistance against Vibrio alginolyticus. Fish Shellfish Immunol. 2010, 28, 764-773.

60. Bradford, M.N. A rapid and sensitivity method for the quantitation of microgram quantities of protein using the principle of protein-dye binding. Anal. Biochem. 1976, 72, 248-254.

61. Cheng, S.Y.; Chen, J.C. Study on the oxyhemocyanin, deoxyhemocyanin, oxygen affinity and acid-base balance of Marsupenaeus japonicus following exposure to combined elevated nitrite and nitrate. Aquat. Toxicol. 2002, 61, 181-193.

62. Lin, Y.C.; Chen, J.C.; Man, S.N.; Morni, W.Z.; Suhaili, A.S.N.; Cheng, S.Y.; Hsu, C.H. Modulation of innate immunity and gene expressions in white shrimp Litopenaeus vannamei following long-term starvation and re-feeding. Results Immunol. 2012, 2, 148-156.

(C) 2015 by the authors; licensee MDPI, Basel, Switzerland. This article is an open access article distributed under the terms and conditions of the Creative Commons Attribution license (http://creativecommons.org/licenses/by/4.0/). 